\title{
The influence of excessive rainfall on the protective value of windscreens with respect to crop yields ${ }^{2}$
}

\author{
SYED RIAZ HUSSAIN SHAH \\ Research Associate at the Institute for Biological Field Research (Itbon), \\ Arnhem, Netherlands
}

\section{Summary}

This research was carried out with artificial screens in order to determine the influence of windscreens for the development and yield of pods in bean (Phaseolus vulgaris) crop. This research revealed the following facts:

1. In the first months the growth of the crop was better under the protected than in the open area.

2. The number of pods in the protected area attained a lead of $60 \%$ in the course of the months of May, June and July, when the rainfall was normal for the Netherlands climate.

3. Then this lead began to decrease. The reason was that the abnormal heavy rains started giving a negative influence to the windscreen. In the protected area, due to low wind velocity contributed by the windscreen, the excessive moisture accumulated in great amount, consequently plant diseases invaded and destroyed the pods as well as some other parts of the plant. Hence the initial surplus of $60 \%$ in the yield of pods was lost. In the open area the winds dried the soil quicker, consequently there was only very little damage to the crop by heavy rains.

4. The author points out that in the regions where very heavy rains are anticipated, a great caution and a good analysis of the situation is needed before a shelterbelt project is carried out for increasing the crop yields.

5. The author adds that each crop behaves in a different way to the accumulation of moisture. In certain crops the damage may be high and in others low. If the crops are of the type which has no or little damage from the execssive moisture for a short period, it is recommended that shelterbelts or windbreaks should be established for increasing the yield of crops.

\section{General introduction}

Wind protection for agricultutral purposes is obtained by many kinds of windscreens. Shelterbelts and windbreaks are the most important ones. Both are barriers of living trees and shrubs, the first consisting of three to twenty rows of trees according to different local circumstances and principally maintained for protecting farm fields, and the second of only one or two rows of trees for the protection of the farm home, other buildings, garden, orchard, and feedlots.

The difference in design and construction of shelterbelts results in better protective efficiency than windbreaks can provide. Hence shelterbelts are preferred over windbreaks when a large scale shelter programme is carried out. However, it will be fair to say that to do this most economically, in many countries it is essential to combine

1 Also published as Meded. Nr. 56/1962 of the Institute for Biological Field Research (Instituut voor Toegepast Biologisch Onderzoek in de Natuur (Itbon)), Arnhem, Netherlands.

Received for publication 12th August, 1961. 
the windbreaks with the shelterbelts according to the microclimate and local conditions.

The major advantage of windscreens is that they reduce wind velocity, which in turn brings about many beneficial results. Wind erosion and silting of canals or ditches is reduced. Soil moisture is increased. Important above all, striking increases in yield of most crops are due to them. Further, living windscreens provide fuelwood and timber for the use of farmers, and protection to man and livestock from cold winds of winter and hot winds of summer.

In many cases far outweighed by these benefits, there can be, however, a few disadvantages. The major ones are:

A. Reduction of the effective agricultural acreage;

B. Competition for light, moisture, and soil nutrients between the trees and the adjoining strip of the crop;

C. Obstruction of mechanized farming;

D. Less possibility for drying in a wet period.

The great benefits from windscreens created a corresponding interest in many countries all over the world to use them. In the western European countries where there is shortage of land, intensive study was started on their influences on the microclimate and crops. In the Netherlands also a research programme was started. The author cooperated in it by conducting some experiments.

In the Netherlands and similar countries there is a high amount of rainfall, which sometimes can be distributed abnormally at the odd parts of the growing season. This paper is designed to make the analyses of excessive rainfall with respect to crop yield under wind protection. The author will be able to bring forward some of the adverse effects of the excessive rainfall on the protective value of windscreens and will finally point out his recommendations.

\section{Methodology of the experiment}

Five different field experiments were carried out in various parts of the Netherlands. In this paper, only the results with beans at Bruinisse (Zeeland) are discussed. The concerning field was acquired in the Agricultural Experiment Station at that place and was used to a width of $12 \mathrm{~m}$ and a length of $80 \mathrm{~m}$. The orientation of the field was such as to face the winds coming from southwest. The soil had a good fertility, which was fairly distributed.

On May 7th, 1960, beans Phaseolus vulgaris cult. $N-150^{1}$ were sown. For the protection from the southwesterly winds, the author designed a special windscreen, which was $1 \mathrm{~m}$ in height and $12 \mathrm{~m}$ in length. It consisted of vertical strips of colourless plastic in wooden frames and was designed in such a way as to keep $33 \%$ airdrainage through it.

There are a few great advantages for using artificial screens for experimental research work :

A. It gives the research worker a chance to find his experiment field in open area and according to his crops requirement;

B. There is no shading effect as of a natural screen on the adjoining strip of the field crop;

1 In America this bean is called "field-bean". 
C. There is also no competition for the soil nutrients and light, etc., between trees and the adjoining strip of the crop.

The screen was fixed in the field so as to divide it into two sections:

1. in front of the screen an area which was unprotected and open for the southwesterly winds;

2. in the leeward side an area which to varying degrees was protected from them.

\section{Observations}

A couple of days after the crop was sown, the screen was fixed. The experimental field was weeded out regularly. A good watch was kept if any external or abnormal factors were interfering with the growth of the plants. Regular visits were made to check the behaviour and the development of the plants.

As soon as the pods gave their first appearance, the author started his proper observations, i.e. countings of the total number of pods in the sampling plots. In total there were five of these countings, viz. on July 11, July 30, August 13, August 29 and September 16, when the plants were 65,84, 98, 114 and 132 days respectively. The sampling comprised 50 different plots of 15 plants each, viz. 40 in the leeward and 10 in the windward side of the screen. According to their place in respect of the screen, they were indicated as $1 \mathrm{H}_{1}, 2 \mathrm{H}_{1}, 3 \mathrm{H}_{1}, 4 \mathrm{H}_{1}, 5 \mathrm{H}_{1}$ till $40 \mathrm{H}_{1}$ (leeward) and $1 \mathrm{H}_{\mathrm{w}}, 2 \mathrm{H}_{\mathrm{w}}, 3 \mathrm{H}_{\mathrm{w}}$ till $10 \mathrm{H}_{\mathrm{w}}$ (windward). Each " $\mathrm{H}_{1}$ " and " $\mathrm{H}_{\mathrm{w}}$ " denotes the height of the screen, i.e. $1 \mathrm{~m}$.

Informations regarding rainfall and temperature are given in the TABLES 1 and 3, those regarding wind conditions in FIGURE 2 and TABLE 2.

\section{Results}

In the first place, the author noticed the better development and growth of the plants in the protected zone than of the plants which were open to the winds.

The results of the five main observations can be seen in FIG. 1. Analysis showed the following: in observation 1 (July 11) the number of pods was $40 \%$ higher in the protected than in the unprotected area, in obcervations 2 and 3 (July 30 and August 13) even $60 \%$ higher, in observation 4 (August 29 ) only $30 \%$, and in observation 5 (September 16) the numbers in the two areas were the same. So, the promising surplus of numbers in the protected area underwent a sudden decline in August, and at the end there was no surplus at all. Further, the moment in which the obviously positive influence of the windscreen started to decrease corresponded with the beginning of a period of abnormal and excessive rainfall, in the months of August and September (see TABLE 1). It seems reasonable to suppose that there must be some connection between this excessive rainfall and the decrease of the number of pods.

\section{Discussion}

In a region suffering from very high rainfall, as was the case in August and September 1960 in Zeeland, a negative influence on the yield may be expected from wind protection if in the same period the windscreen is effective indeed. Then, as a matter of fact, the wind reduction is detrimental because it retards the evaporation. 
Probably by the accumulation of excessive moisture, the different plant diseases come in and the plants under the windscreen protected area starts rotting.

Moreover, the water supply within the plant may determine cell size. If for a certain period of time the in-coming of water is greater than the out-going, the water pressure within the plant increases and the cells just back of the growing points are elongated. The increasing supplies of water may result in growth cracks. Furthermore, a great amount of excessive moisture in the soil may inhibit the growth of roots due to absence of oxygen in the soil.

The author therefore strongly recommends to take caution before establishing shelterbelts or windbreaks for especially increasing the yield of crops in the regions with an extreme wet climate. As a matter of fact, in the countries with a wet climate and with low temperatures little practical value may be expected from a programme for the establishment of such windscreens. But it is to be added that the different crops react to the accumulation of moisture in different way from each other. Certain crops are extremely sensitive and are damaged greatly, while others are perhaps less sensitive, hence are not damaged badly. The relation of the climate and the influence of windscreens on the yield of the different crops have to be investigated for each case and for each crop before the windscreens establishment programme is carried out.

TABlE 1. Rainfall in Zeeland during the growing season of $1960^{1}$

\begin{tabular}{|c|c|c|c|c|}
\hline Month & Time period & $\begin{array}{c}\text { Total quantity } \\
\text { of rainfall } \\
\mathrm{mm}\end{array}$ & $\begin{array}{l}\text { Number of } \\
\text { hours rainfall }\end{array}$ & $\begin{array}{c}\text { Thunder and } \\
\text { lightning }\end{array}$ \\
\hline May & $\begin{array}{l}\text { First } 10 \text { days } \ldots \ldots \ldots \ldots \ldots \ldots \ldots \\
\text { Second } 10 \text { days } \ldots \ldots \ldots \ldots \ldots \ldots \ldots \\
\text { Last } 11 \text { days } \ldots \ldots \ldots \ldots \ldots \ldots \\
\text { Total of month } \ldots \ldots \ldots \ldots \ldots \ldots \\
\text { Av. of last } 30 \text { years } \ldots \ldots \ldots \ldots \ldots\end{array}$ & $\begin{array}{r}1 \\
29 \\
28 \\
57 \\
49\end{array}$ & $\begin{array}{r}1 \\
17 \\
15 \\
33 \\
-\end{array}$ & $\frac{-}{1}$ \\
\hline June & 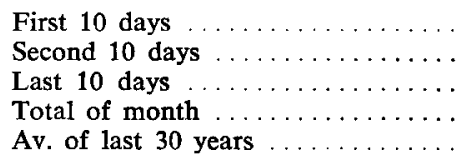 & $\begin{array}{r}10 \\
13 \\
6 \\
29 \\
52\end{array}$ & $\begin{array}{r}11 \\
4 \\
4 \\
20 \\
-\end{array}$ & $\frac{-1}{1}$ \\
\hline July & $\begin{array}{l}\text { First } 10 \text { days } \ldots \ldots \ldots \ldots \ldots \ldots \\
\text { Second } 10 \text { days } \ldots \ldots \ldots \ldots \ldots \ldots \\
\text { Last } 11 \text { days } \ldots \ldots \ldots \ldots \ldots \\
\text { Total of month } \ldots \ldots \ldots \ldots \ldots \\
\text { Av. of last } 30 \text { years } \ldots \ldots \ldots \ldots\end{array}$ & $\begin{array}{l}24 \\
21 \\
36 \\
81 \\
66\end{array}$ & $\begin{array}{r}21 \\
7 \\
22 \\
50 \\
-\end{array}$ & $\begin{array}{r}- \\
-3 \\
4\end{array}$ \\
\hline Aug. & $\begin{array}{l}\text { First } 10 \text { days } \ldots \ldots \ldots \ldots \ldots \ldots \\
\text { Second } 10 \text { days } \ldots \ldots \ldots \ldots \ldots \ldots \\
\text { Last } 11 \text { days } \ldots \ldots \ldots \ldots \ldots \\
\text { Total of month } \ldots \ldots \ldots \ldots \ldots \ldots \\
\text { Av. of last } 30 \text { years } \ldots \ldots \ldots \ldots \ldots\end{array}$ & $\begin{array}{r}15 \\
66 \\
44 \\
125 \\
63\end{array}$ & $\begin{array}{l}15 \\
28 \\
10 \\
53 \\
-\end{array}$ & $\frac{1}{1}$ \\
\hline Sept. & $\begin{array}{l}\text { First } 10 \text { days } \ldots \ldots \ldots \ldots \ldots \\
\text { Second } 10 \text { days } \ldots \ldots \ldots \ldots \ldots \ldots \\
\text { Last } 10 \text { days } \ldots \ldots \ldots \\
\text { Total of month } \ldots \ldots \ldots \ldots \\
\text { Av, of last } 30 \text { years } \ldots \ldots \ldots \ldots \ldots\end{array}$ & $\begin{array}{r}38 \\
17 \\
59 \\
114 \\
74\end{array}$ & $\begin{array}{l}10 \\
27 \\
27 \\
64 \\
-\end{array}$ & $\frac{-}{-}$ \\
\hline
\end{tabular}

1 Sources of TABLES 1-3: Royal Netherlands Meteorological Institute at De Bilt. 
FIG. 1. The development of the number of bean pods under the protection of the artificial windscreen at Bruinisse (Zeeland)

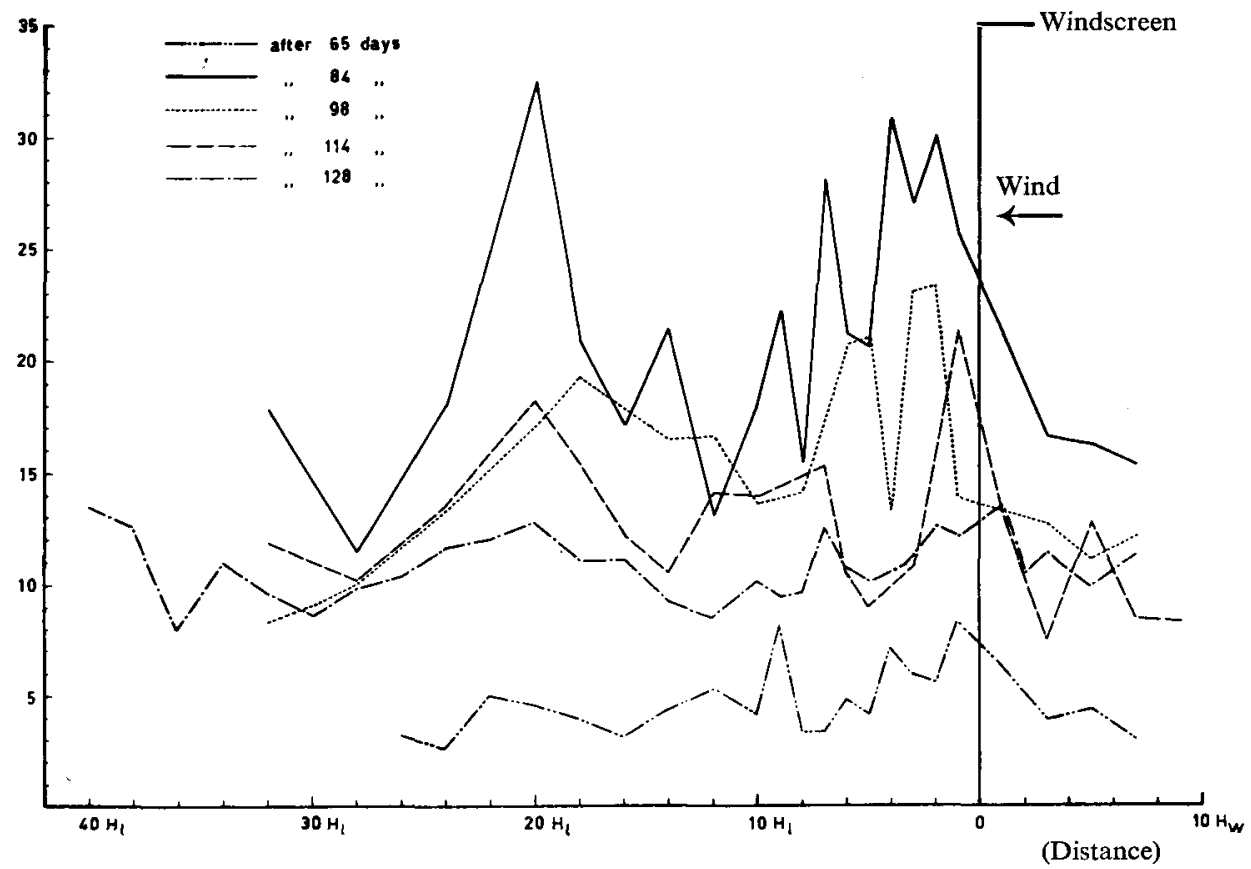

FIG. 2. Winds during the growing season of 1960 in Zeeland. Their procentual distribution is indicated by the width of marks, and their medium velocity by the length (up to outer rim of compass-cards $=5 \mathrm{~m} / \mathrm{sec}$ )
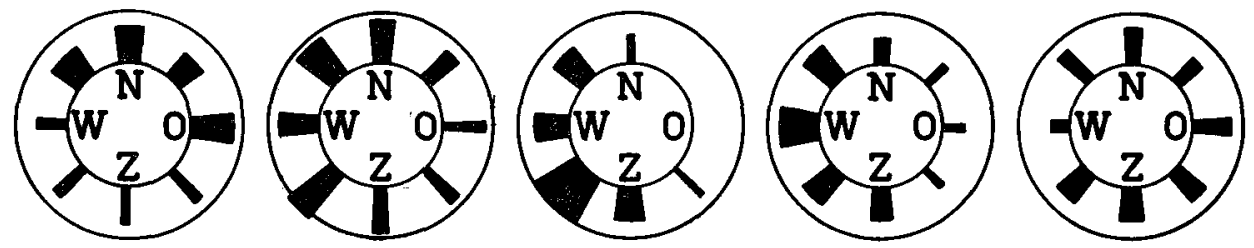

May 1960
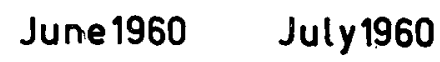

Aug. 1960

Sept.1960
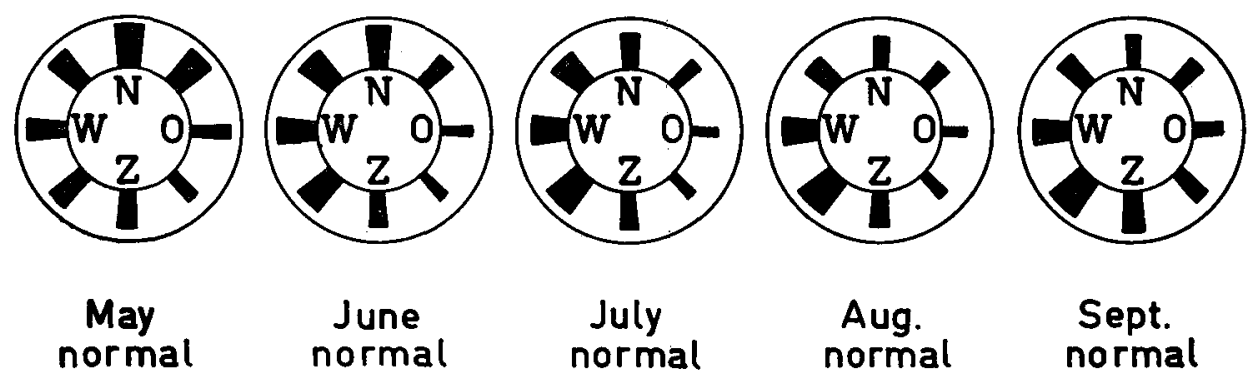

\section{Sept.} normal 
TABLE 2. Wind conditions in Zeeland during the growing season of 1960

\begin{tabular}{|c|c|c|c|c|c|c|c|c|c|c|c|c|c|c|c|c|c|c|}
\hline \multirow[t]{2}{*}{ Month } & \multirow[t]{2}{*}{ Time period } & \multicolumn{2}{|c|}{ North } & \multicolumn{2}{|c|}{ North- } & \multicolumn{2}{|c|}{$\begin{array}{l}\text { East } \\
\text { east }\end{array}$} & \multicolumn{2}{|c|}{ South- } & \multicolumn{2}{|c|}{$\begin{array}{c}\text { South } \\
\text { east }\end{array}$} & \multicolumn{2}{|c|}{$\begin{array}{l}\text { South- } \\
\text { west }\end{array}$} & \multicolumn{2}{|c|}{ West } & \multicolumn{2}{|c|}{$\begin{array}{l}\text { North- } \\
\text { west }\end{array}$} & \multirow{2}{*}{$\begin{array}{c}\text { No } \\
\text { wind } \\
\%\end{array}$} \\
\hline & & $\%$ & $\mathbf{V}$ & 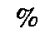 & $\mathbf{V}$ & $\%$ & V & $\%$ & V & $\%$ & V & $\sigma$ & $\mathbf{V}$ & $\%$ & $\mathbf{V}$ & $\%$ & 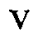 & \\
\hline May & $\begin{array}{l}\text { First } 10 \text { days } \ldots \\
\text { Second } 10 \text { days } \ldots \\
\text { Last } 11 \text { days } \ldots \\
\text { Av. of month } \ldots \\
\text { Av. of last } 30 \text { years }\end{array}$ & $\begin{array}{l}20 \\
34 \\
25 \\
17\end{array}$ & $\begin{array}{l}4 \\
4 \\
5 \\
4 \\
4\end{array}$ & $\begin{array}{l}12 \\
21 \\
17\end{array}$ & $\begin{array}{l}4 \\
4 \\
4 \\
4 \\
5\end{array}$ & $\begin{array}{r}16 \\
20 \\
2 \\
12 \\
11\end{array}$ & $\begin{array}{l}3 \\
5 \\
4\end{array}$ & $\begin{array}{l}4 \\
5 \\
5 \\
5 \\
6\end{array}$ & $\begin{array}{l}5 \\
4 \\
3 \\
4 \\
3\end{array}$ & 9 & $\begin{array}{l}3 \\
5\end{array}$ & $\begin{array}{l}3 \\
3 \\
8 \\
5 \\
14\end{array}$ & $\begin{array}{l}3 \\
3 \\
4 \\
3 \\
5\end{array}$ & $\begin{array}{l}11 \\
11 \\
12\end{array}$ & $\begin{array}{l}5 \\
4 \\
5\end{array}$ & $\begin{array}{r}7 \\
14 \\
10 \\
10\end{array}$ & + & $\begin{array}{l}7 \\
-6 \\
5 \\
1\end{array}$ \\
\hline in & $\begin{array}{l}\text { First } 10 \text { days } \ldots \\
\text { Second } 10 \text { days } \ldots \\
\text { Last } 10 \text { days } \ldots \\
\text { Av. of month } \ldots \\
\text { Av. of last } 30 \text { years }\end{array}$ & $\begin{array}{l}13 \\
33 \\
19\end{array}$ & $\begin{array}{l}5 \\
6 \\
6 \\
6 \\
4\end{array}$ & $\begin{array}{r}15 \\
2 \\
10 \\
9 \\
11\end{array}$ & $\begin{array}{l}4 \\
5 \\
4 \\
5 \\
4\end{array}$ & $\begin{array}{r}17 \\
1 \\
9 \\
9 \\
7\end{array}$ & 3 & $\begin{array}{l}6 \\
1 \\
3 \\
3 \\
4\end{array}$ & $\begin{array}{l}4 \\
2 \\
3 \\
4 \\
3\end{array}$ & $\begin{array}{r}8 \\
7 \\
5\end{array}$ & $\frac{5}{5}$ & $\begin{array}{l}1 \\
20 \\
16\end{array}$ & $\begin{array}{l}9 \\
8 \\
6 \\
8 \\
6\end{array}$ & $\begin{array}{l}20 \\
31 \\
14 \\
22 \\
26\end{array}$ & $\begin{array}{l}7 \\
7 \\
6 \\
7 \\
6\end{array}$ & $\begin{array}{r}3 \\
4 \\
32 \\
13 \\
15\end{array}$ & $\begin{array}{l}5 \\
3\end{array}$ & $\begin{array}{l}- \\
0 \\
0 \\
0 \\
1\end{array}$ \\
\hline 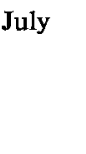 & $\begin{array}{l}\text { First } 10 \text { days } \ldots . \\
\text { Second } 10 \text { days } \ldots \\
\text { Last } 11 \text { days } \ldots \\
\text { Av. of month } \ldots \\
\text { Av. of last } 30 \text { years }\end{array}$ & $\begin{array}{l}6 \\
3 \\
6 \\
5 \\
9\end{array}$ & $\begin{array}{l}5 \\
5 \\
3 \\
4 \\
3\end{array}$ & $\begin{array}{l}- \\
4 \\
1 \\
9\end{array}$ & $\begin{array}{l}- \\
2 \\
2 \\
3\end{array}$ & $\begin{array}{l}- \\
- \\
0 \\
7\end{array}$ & 3 & $\begin{array}{l}5 \\
3 \\
2 \\
5\end{array}$ & $\begin{array}{r}5 \\
6 \\
-5 \\
5\end{array}$ & $\begin{array}{r}11 \\
18 \\
6 \\
11 \\
10\end{array}$ & $\begin{array}{l}5 \\
8 \\
6 \\
7 \\
5\end{array}$ & 20 & $\begin{array}{l}9 \\
8 \\
6 \\
8 \\
6\end{array}$ & $\begin{array}{l}20 \\
25 \\
37 \\
28 \\
28\end{array}$ & $\begin{array}{l}7 \\
7 \\
6 \\
6 \\
6\end{array}$ & $\begin{array}{r}23 \\
3 \\
14 \\
13 \\
13\end{array}$ & 5 & $\begin{array}{l}- \\
2 \\
1 \\
0\end{array}$ \\
\hline Aug. & $\begin{array}{l}\text { First } 10 \text { days } \ldots \\
\text { Second } 10 \text { days } \\
\text { Last } 11 \text { days } \ldots \\
\text { Av. of month } \ldots \\
\text { Av. of last } 30 \text { years }\end{array}$ & $\begin{array}{r}18 \\
11 \\
2 \\
10 \\
10\end{array}$ & $\begin{array}{l}4 \\
5 \\
2 \\
4 \\
3\end{array}$ & $\begin{array}{r}10 \\
13 \\
3 \\
8 \\
9\end{array}$ & $\begin{array}{l}3 \\
3 \\
3 \\
3 \\
4\end{array}$ & $\begin{array}{l}3 \\
4 \\
6 \\
4 \\
8\end{array}$ & 3 & $\begin{array}{r}2 \\
4 \\
10 \\
5 \\
5\end{array}$ & $\begin{array}{l}4 \\
4 \\
4 \\
3\end{array}$ & $\begin{array}{r}5 \\
8 \\
15 \\
9 \\
11\end{array}$ & $\begin{array}{l}5 \\
5\end{array}$ & $\begin{array}{l}22 \\
24\end{array}$ & $\begin{array}{l}5 \\
7 \\
7 \\
7 \\
6\end{array}$ & $\begin{array}{l}18 \\
20 \\
28 \\
22 \\
24\end{array}$ & $\begin{array}{l}5 \\
7 \\
7 \\
7 \\
6\end{array}$ & $\begin{array}{r}18 \\
12 \\
9 \\
13 \\
11\end{array}$ & $\begin{array}{l}3 \\
6\end{array}$ & $\begin{array}{l}\frac{1}{2} \\
1 \\
1\end{array}$ \\
\hline Sept. & $\begin{array}{l}\text { First } 10 \text { days } \ldots \\
\text { Second } 10 \text { days } \ldots \\
\text { Last } 10 \text { days } \ldots \\
\text { Av. of month } \ldots \\
\text { Av. of last } 30 \text { years }\end{array}$ & $\begin{array}{r}8 \\
10 \\
12 \\
10 \\
9\end{array}$ & $\begin{array}{l}3 \\
4 \\
3 \\
4 \\
3\end{array}$ & $\begin{array}{r}4 \\
8 \\
27 \\
13 \\
11\end{array}$ & $\begin{array}{l}2 \\
4 \\
4 \\
4 \\
3\end{array}$ & $\begin{array}{r}3 \\
20 \\
27 \\
16 \\
10\end{array}$ & 3 & $\begin{array}{r}3 \\
24 \\
4 \\
4 \\
12 \\
6\end{array}$ & 3 & $\begin{array}{r}8 \\
10 \\
9 \\
12 \\
16\end{array}$ & 4 & $\begin{array}{r}33 \\
5 \\
8 \\
15\end{array}$ & $\begin{array}{l}7 \\
5 \\
5 \\
6 \\
6\end{array}$ & $\begin{array}{r}18 \\
3 \\
5 \\
9 \\
19\end{array}$ & $\begin{array}{r}6 \\
9 \\
10 \\
7 \\
6\end{array}$ & $\begin{array}{r}18 \\
6 \\
7 \\
10 \\
10\end{array}$ & $\begin{array}{r}4 \\
8 \\
10 \\
6 \\
4\end{array}$ & $\begin{array}{l}6 \\
0 \\
1\end{array}$ \\
\hline
\end{tabular}

$\%=$ Number of hours in percentages; $\mathrm{V}=$ Average velocity in $\mathrm{m} / \mathrm{sec}$.

TABLE 3. Temperatures (in ${ }^{\circ} \mathrm{C}$ ) in Zeeland during the growing season of 1960

\begin{tabular}{|c|c|c|c|c|c|}
\hline Month & Time period & $\begin{array}{l}\text { Average } \\
24 \text { hours }\end{array}$ & $\begin{array}{l}\text { Average } \\
\text { daytime }\end{array}$ & $\begin{array}{l}\text { Average } \\
\text { daily max. }\end{array}$ & $\begin{array}{c}\text { Average } \\
\text { daily min. }\end{array}$ \\
\hline May & $\begin{array}{l}\text { First } 10 \text { days } \ldots \ldots \ldots \\
\text { Second } 10 \text { days } \ldots \ldots \ldots \\
\text { Last } 11 \text { days } \ldots \ldots \ldots \\
\text { Av. of month } \ldots \ldots \ldots \\
\text { Av. of last } 30 \text { years } \ldots \ldots\end{array}$ & $\begin{array}{l}12,5 \\
13,6 \\
12,8 \\
13,0 \\
12,0\end{array}$ & $\begin{array}{l}14,1 \\
14,2 \\
13,6 \\
14,0 \\
13,0\end{array}$ & $\begin{array}{l}17,4 \\
17,2 \\
15,6 \\
16,7 \\
15,9\end{array}$ & $\begin{array}{r}8,1 \\
10,9 \\
10,6 \\
9,9 \\
8,9\end{array}$ \\
\hline June & $\begin{array}{l}\text { First } 10 \text { days } \ldots \ldots \ldots \\
\text { Second } 10 \text { days } \ldots \ldots \ldots \\
\text { Last } 10 \text { days } \ldots \ldots \ldots \\
\text { Av. of month } \ldots \ldots \ldots \\
\text { Av. of last } 30 \text { years } \ldots \ldots\end{array}$ & $\begin{array}{l}16,3 \\
15,6 \\
15,8 \\
15,9 \\
15,0\end{array}$ & $\begin{array}{l}17,5 \\
16,7 \\
16,7 \\
17,0 \\
16,1\end{array}$ & $\begin{array}{l}20,5 \\
19,3 \\
19,4 \\
19,7 \\
18,7\end{array}$ & $\begin{array}{l}12,8 \\
12,7 \\
13,4 \\
12,9 \\
12,0\end{array}$ \\
\hline July & $\begin{array}{l}\text { First } 10 \text { days } \ldots \ldots \ldots \\
\text { Second } 10 \text { days } \ldots \ldots \ldots \\
\text { Last } 11 \text { days } \ldots \ldots \ldots \ldots \\
\text { Av. of month } \ldots \ldots \ldots \\
\text { Av. of last } 30 \text { years } \ldots \ldots\end{array}$ & $\begin{array}{l}15,2 \\
16,1 \\
16,4 \\
15,9 \\
17,2\end{array}$ & $\begin{array}{l}16,0 \\
17,2 \\
17,2 \\
16,8 \\
18,2\end{array}$ & $\begin{array}{l}17,8 \\
18,9 \\
18,9 \\
18,5 \\
20,9\end{array}$ & $\begin{array}{l}13,0 \\
13,7 \\
14,3 \\
13,7 \\
14,3\end{array}$ \\
\hline Aug. & $\begin{array}{l}\text { First } 10 \text { days } \ldots \ldots \ldots \\
\text { Second } 10 \text { days } \ldots \ldots \ldots \\
\text { Last } 11 \text { days } \ldots \ldots \ldots \\
\text { Av. of month } \ldots \ldots \ldots \\
\text { Av. of last } 30 \text { years } \ldots \ldots\end{array}$ & $\begin{array}{l}17,0 \\
15,5 \\
17,6 \\
16,7 \\
17,3\end{array}$ & $\begin{array}{l}18,0 \\
16,1 \\
18,3 \\
17,5 \\
18,2\end{array}$ & $\begin{array}{l}20,6 \\
18,3 \\
20,7 \\
19,9 \\
20,8\end{array}$ & $\begin{array}{l}13,9 \\
13,2 \\
15,6 \\
14,3 \\
14,4\end{array}$ \\
\hline Sept. & $\begin{array}{l}\text { First } 10 \text { days } \ldots \ldots \ldots \\
\text { Second } 10 \text { days } \ldots \ldots \ldots \\
\text { Last } 10 \text { days } \ldots \ldots \ldots \\
\text { Av. of month } \ldots \ldots \ldots \\
\text { Av. of last } 30 \text { years } \ldots \ldots\end{array}$ & $\begin{array}{l}15,5 \\
16,2 \\
12,8 \\
14,8 \\
15,3\end{array}$ & $\begin{array}{l}15,9 \\
16,9 \\
13,3 \\
15,4 \\
15,9\end{array}$ & $\begin{array}{l}18,1 \\
19,6 \\
15,7 \\
17,8 \\
18,5\end{array}$ & $\begin{array}{l}13,5 \\
14,0 \\
10,1 \\
12,6 \\
12,8\end{array}$ \\
\hline
\end{tabular}




\section{ACKNOWLEDGEMENT}

The author expresses his gratitude to Dr. Ir. C. W. C. van BeEkom, Agricultural Advisor to the Province of Zeeland, at Goes, for his cooperation in providing the help to the author in conducting the research successfully.

\section{B I B L I O G R A P H Y}

Bates, C. G.

DENUYL, D.

George, E. S.

LINDE, R. J. VAN DER, and J. P. M. WOUdenBerG

LINDE, R. J. VAN DER

RHEE, J. A.

SaId, Mohammed

Shah, Syed Riaz Hussain
1911 Windbreaks, their influence and value. U.S. Dep. Agr., Forest Service Bull. No. 86, 1-100.

1948 How shelterbelts benefit crops. J. of For. 46, No. 10, 767768.

1943 Windbreaks for protecting muck soils and crops. Purdue Univ. Agr. Exp. Stat., Lafayette (U.S.A.), Circ. No. 287, $1-12$.

1957 Shelterbelts for the Northern Great Plains. U.S. Dep. Agr. Farmer's Bull. No. 2109, 1-15.

1951 On the microclimate properties of sheltered areas. The oakcoppice sheltered area. Inst. Biol. Field Res. (Itbon), Arnhem, Meded. No. 10, 1-15.

1958 Het probleem van de houtopstanden in het cultuurlandschap. Centrum Landbouwdoc., Wageningen, Lit, Overzicht No. 21.

1959 Windbeschutting van cultuurgewassen, vooral onderzocht voor fruit. Inst. Biol. Field Res. (Itbon), Arnhem, Meded. No. 43.

1954 Effect of shelterbelt on soil moisture. Pakistan J. of For. 4, 3 : 175-179.

1959 The shelterbelt program in the United States and its possible adaptation to West Pakistan. Thesis Master of Forestry degree Syracuse Univ. (unpublished) pp. 160.

1960 The economic analysis for the establishment of the shelterbelts project in West Pakistan. Agriculture Pakistan. 11, No. 3, $465-473$.

1960 The shelterbelts : an asset to the nation. Agriculture Pakistan. 11, No. 4, 526-539. 